The Journal of Black Psychology

Spring 1989, Vol. 15, No. 2, Pp. 111-128

\title{
Delay of Gratification Among Black College Student Leaders
}

\author{
Wanda E. Ward \\ T. Bridgett Perry \\ Jon Woltz \\ Estrellita Doolin \\ University of Oklahoma
}

\begin{abstract}
The purpose of this research was to examine the existence of multidimensionality in delay of gratification for Black university student leaders. We investigated delay preference as it related to academic decisions, career choices, sociopolitical issues, and consumer preferences. Results supported such multidimensionality by yielding evidence for the heretofore unexamined sociopolitical dimension as well as an achievement-oriented delay dimension in this sample of Black students. Gender differences are also reported. Results indicated that similar factor structures emerged for both sexes. The importance of this approach to the study of delay is discussed as well as directions for future research.
\end{abstract}

\footnotetext{
We gratefully acknowledge the assistance of N. Jack Kanak, Michelle Saulters, Suzie Riddlebarger, and Anthony Zeigler in the conducting of this study. We are also grateful to W. Curtis Banks, Thomas J. Berndt, and W. Alan Nicewander for their comments on this manuscript.
}

The research reported here was supported by the Office of Research Administration, University of Oklahoma.

Correspondence concerning this article should be addressed to Wanda E. Ward, Center for Research on Minority Education, University of Oklahoma, Norman, Oklahoma 73019. 
In the study of self-regulation, the construct of delay of gratification has received considerable attention. Delay of gratification has been conceptualized as the ability to forego immediate rewards, opportunities, or needs in favor of alternative opportunities, needs, or rewards that are of greater value but are more temporally remote. As with other self-regulatory concepts, like willpower, mastery, competence, helplessness, and hopelessness, inherent in the notion of delay of gratification are notions of volition and individuals' ability to influence their own outcomes and personal environment (Mischel, 1986). Such self-imposed behavior is often assumed to be fundamental to numerous conceptualizations of complex human behavior and personality development. Mischel stated:

Sometimes this influence is judged to be for the social good, and therefore prosocial or "moral"'; often it is not. Always it involves the individual's efforts to modify conditions and to self-regulate and increase mastery in the light of particular goals . . . . One especially striking characteristic of human "will" is that people frequently impose barriers on themselves, interrupting their own behavior and delaying available gratification. (p. 414)

Mischel (1974) proposed a two-staged process in the delay of gratification. The first stage focuses on the determinants (e.g., expectancies) of one's choice to delay and the second on factors that facilitate delay behavior. Such facilitative factors include (1) desired rewards are not visibly present; and (2) cognitive representations and ideational activity that distract a person from consummatory qualities he is awaiting. The basic paradigm used to investigate this phenomenon consists of presenting subjects the choice between two alternative rewards for their participation in an experiment, i.e., subjects choose between a smaller reward to be presented immediately by the experimenter or a larger, more valued reward to be received at a later point in time. Most investigations in this area employ the actual reward choice and/or hypothetical inquiries. Examples of hypothetical items used to reflect choice situations include: "I would rather get $\$ 10$ now or wait a whole month and get $\$ 30$ then" (Mischel, 1961; Price-Williams \& Ramirez, 1974); and "If wearing ugly braces would make my teeth look prettier later on, I would put up with looking awful for a year or two" (Lessing, 1969).

Our research involved the theoretical expansion of the delay of gratification construct by examining its multidimensional aspects. Previous investigations have overlooked the importance of such examination. Although much of recent research has focused on the second stage of Mischel's two-staged process (see Mischel, 1986), it is important to understand more fully the 
determinants of choice patterns of delay. Identification of distinguishable dimensions of delay of gratification leads to a fuller understanding of how and in which domains this phenomenon operates. One might explore, therefore, several dimensions of choice patterns of delay: personal commodities, academic orientation, career orientation, and sociopolitical activity.

It is generally acknowledged that people demonstrate delay preferences in areas such as consumer behavior, academic and career pursuits (e.g., science), but it appears that the issue of sociopolitical delay of gratification has gone unexamined empirically (see, for example, research by Gurin, Gurin, Lao, \& Beattie, 1969, for a discussion of sociopolitical aspects of locus of control construct).

Clear examples, however, of such sociopolitical delay behavior can be pointed to readily. Throughout struggles for freedom and equal opportunity, Blacks have demonstrated their capability to forego immediate gains and needs of perceived lesser value in favor of more highly prized, but distant goals (e.g., in the form of boycotts). The self-selected denial of more immediate necessities (e.g., food, transportation to work, etc.) for the sake of better, but more distant, long-term goals (e.g., housing, education, jobs, and greater freedom itself) demonstrates persuasively such individuals' capacity to exert influence on their own outcomes and personal environments and for the social good.

The need to examine such aspects of delay of gratification is demonstrated further by efforts to study the influence of this factor in areas such as academic success. For example, attempts to explain the academic status of minorities have broadened over the years to include not only traditional academic indices such as comparative differences between minorities and Whites on standardized tests, but also nonacademic variables that emphasize unique aspects of minority experiences (see, for example, Sedlacek \& Brooks, 1976; Tracey \& Sedlacek, 1984, 1985, 1986; Thomas, 1981). Sedlacek and colleagues have investigated the influence of several variables on the academic success of Black students. The variables include: (1) positive self-concept, (2) realistic self-appraisal, (3) understanding of and ability to deal with racism, (4) availability of a strong support person, (5) successful leadership experience, (6) demonstrated community experience, and (7) preference for long-term goals over short-term or immediate goals (i.e., delay of gratification). In this report, we focus on the last variable only.

Sedlacek and colleagues have used three hypothetical items to measure delay preference: " Once I start something I finish it"; "I get easily discouraged when I try to do something and it does not work"; and a listing of academic relatedness of the individual's three most primary goals. Tracey and Sedlacek (1984) report good support for the reliability and construct validity 
of their Non-Cognitive Questionnaire (Sedlacek \& Brooks, 1976) for Black college students. Factor analysis revealed a structure of eight factors, one of which was delay of gratification.

Sedlacek and others, however, have tended to use a global definition of delay of gratification, which may explain the mixed results obtained about the relationship between this variable and academic success (see, for example, Lessing, 1969). We propose that a more systematic examination of the delay of gratification construct and a more domain-specific operationalization of it is warranted. Therefore, this study investigates the multidimensionality of delay of gratification among Black college student leaders. Specifically we examined the existence of achievement oriented delay, career oriented delay, sociopolitical delay, and consumer delay preference. Toward this end we developed a questionnaire designed to measure these dimensions. The questionnaire was designed to tap experiences and opinions of Black students and often focused on race-related issues. A primary purpose of the study, then, was to establish the construct validity of the multidimensionality underlying delay choice patterns.

We chose to examine these notions among Blacks because of the traditional characterization in the psychological literature of Blacks as being more immediate than delayed gratifiers. Contrary to this traditional characterization, in reviews of the published experimental data, Blacks have been found to display either a pattern of preferring delayed gratification or indifference toward immediate versus delayed reward (see Banks, McQuater, Ross, \& Ward, 1983; Ward, Banks, \& Wilson, in press). Also, we chose to examine these issues among Black student leaders because of the dearth of research conducted on Black leaders and delay of gratification, and because of the importance of better understanding the psychological processes of a segment of society that is expected to expand in an increasingly multicultural society. In this study student leaders consisted of student government officers, sorority and fraternity officers, and students active in university affairs.

\section{Method}

\section{Subjects}

A total of 318 volunteer Black college students were paid five dollars for completing several survey instruments. The subjects completed the instru- 
ments approximately one week prior to attending a Big Eight Black Student Government Leadership Conference at a comprehensive university in the southwest. Five hundred questionnaires were mailed out to the conference registrants who were identified on lists provided by conference organizers. Three hundred twenty-three questionnaires were returned, but five were excluded because they were incomplete. This yielded a response rate of $64 \%$.

Approximately $85 \%$ of the subjects attended public comprehensive universities (13 predominately White institutions were represented by subjects in this study). The sample consisted of 215 females (mean age $=20$ years and 6 months) and 103 males (mean age $=20$ years and 7 months), with the mean age of the sample being 20 years and 6 months. Additionally, for further verification of leadership status, respondents were asked to rate $(1=$ high, 2 = above average, 3 = average, $4=$ below average) an unbiased observer's perception of their leadership abilities. The mean response for this sample was 2.17 , indicating above average perceived leadership capability.

\section{Instruments}

The subjects first completed a questionnaire that provided basic demographic information (i.e., age, sex, classification, etc.) and other information relevant to their college experiences.

Next they completed a questionnaire designed to assess the multiple dimensions of preference for delay of gratification. The questionnaire utilized a forced-choice format in which two alternatives were presented, and the subject was asked to "Mark an X on the line next to the choice they agreed with most." The order of presentation of choices indicating a preference for delay of gratification was alternated with choices indicating a preference for immediate gratification. Responses indicating preference for delay were scored 1, and those reflecting preference for immediate gratification were scored 0 . A total of 30 items was designed to assess preference for delay on the five dimensions, each of which consisted of 6 items. Based on a selected literature review of a variety of items used to assess delay, we generated items that specifically tapped the dimensions being investigated in this study. The scale of 30 items was piloted with 25 Black student leaders, and the results indicated sufficient variation in subjects' responses so that all 30 items were retained for the actual survey. In addition there were 9 filler items randomly dispersed throughout the scale.

The five dimensions of preference for delay and a sample item for each, were as follows: (1) Personal Consumer - (a) I would rather spend the money I make to buy fashionable clothes now, or $(b)$ save the money I make to buy a car in two years; (2) Academic Concerns - (a) I would rather stay in 
school and travel after graduation, or $(b)$ take a year off and travel, even if it means falling behind in school; (3) Career Concerns - (a) I would rather major in a field that requires a great deal of school work because it may lead to a better job after graduation, or $(b)$ major in a field that requires less school work, even if it may not be likely to lead to a better job; (4) Individual Sociopolitical Issues - (a) I would rather not work extra even if it means accepting a scholarship from a company known to support Apartheid, or (b) work extra even if it means not accepting a scholarship from a company that supports Apartheid; (5) Group Sociopolitical Issues - (a) In my opinion, it would be better for Blacks as a group in the long run, if they would boycott retailers who support Apartheid, even if it means doing without preferred goods, or $(b)$ Blacks should purchase their preferred products from whoever has the best "buy" at the time. We examined sociopolitical delay at the individual and group level to assess possible differences in the preference or choice by massive numbers of individuals to delay gratification for the sake of the individual or for the sake of one's group (e.g., ethnic/racial) as a whole.

\section{Results}

\section{Factor Analysis}

The 30 items from the Multidimensional Delay of Gratification scale were subjected to a principal components factor analysis with a varimax rotation. The SAS software package was used to perform the factor analyses. Initial results revealed a multidimensional scale with 11 factors retained by the minimum eigenvalue criterion of 1 or greater. However, several of the factors accounted for very small amounts of variance. That was due primarily to the loading of one item on those factors. Results indicated that two clearly interpretable factors emerged that had relatively high reliability estimates. ${ }^{1}$ Twenty-two of the 30 items loaded significantly on these two factors at a level of .30 or above (see Table 1).

\footnotetext{
${ }^{1}$ For exploratory purposes additional analyses were performed on transformations of the data. Because the raw data exist in binary form, the factor analyses were also executed using a correlation matrix based on tetrachoric correlation coefficients instead of the standard correlation coefficients. However, these analyses actually obscured the interpretation of the existing structures. In fact, the factor structures that resulted from the factor analyses performed on the raw data provide a stronger interpretation based upon the dimensions hypothesized in this study and higher reliability estimates for each factor. Finally, our approach appears consistent with previous research conducted using forced-choice formats when investigating other personality characteristics such as locus of control (see, for example, Gurin et al., 1969; Gurin, Gurin, \& Morrison, 1978).
} 


\section{Table 1}

Factor Analysis of Pool of Delay of Gratification Items

(Black Student Leaders)

\begin{tabular}{|c|c|c|c|c|}
\hline \multirow[b]{2}{*}{ Dimension } & \multirow[b]{2}{*}{ Item\# } & \multirow[b]{2}{*}{$\begin{array}{l}\text { Factor I: Sociopolitical } \\
\text { Factor II: Achievement }\end{array}$} & \multicolumn{2}{|c|}{$\begin{array}{l}\text { Varimax Rotation } \\
\quad \text { Factors }\end{array}$} \\
\hline & & & $I$ & II \\
\hline$S$ & (14) & $\begin{array}{l}\text { Boycott and do without, or buy if discrimi- } \\
\text { nation exists (Grp) }\end{array}$ & .67 & .07 \\
\hline$S$ & (20) & $\begin{array}{l}\text { Blacks take best jobs, or work extra in oppo- } \\
\text { sition to Apartheid (Grp) }\end{array}$ & .66 & -.08 \\
\hline$S$ & (26) & $\begin{array}{l}\text { Blacks refuse to sell to groups supporting } \\
\text { Apartheid or sell to highest bidder (Grp) }\end{array}$ & .58 & .02 \\
\hline$S$ & (11) & $\begin{array}{l}\text { Buy hair products from Black companies, or } \\
\text { buy readily available products (Ind) }\end{array}$ & .52 & .06 \\
\hline$S$ & (23) & $\begin{array}{l}\text { Shop nearby, or go elsewhere to avoid dis- } \\
\text { criminatory practices (Ind) }\end{array}$ & .52 & .07 \\
\hline$S$ & (38) & $\begin{array}{l}\text { Black students not accept scholarship from } \\
\text { Apartheid supporters, or accept regardless } \\
\text { (Grp) }\end{array}$ & .52 & -.08 \\
\hline$S$ & (4) & $\begin{array}{l}\text { Individual accept scholarship, or refuse it } \\
\text { (Ind) }\end{array}$ & .49 & .14 \\
\hline$S$ & (29) & $\begin{array}{l}\text { Campaign for candidate, or not campaign } \\
\text { (Ind) }\end{array}$ & .44 & .14 \\
\hline$S$ & (2) & $\begin{array}{l}\text { Take job with less pay now but more pay } \\
\text { later, or take job with more pay now but few } \\
\text { raises (Career) }\end{array}$ & .40 & .17 \\
\hline$S$ & (16) & $\begin{array}{l}\text { Take job with immediate benefits, or wait for } \\
\text { career job that you really want (Career) }\end{array}$ & .34 & .20 \\
\hline$S$ & (37) & $\begin{array}{l}\text { Take fewer courses and stay in school longer, } \\
\text { or take more courses and year off (Acad) }\end{array}$ & .34 & .19 \\
\hline$S$ & (7) & $\begin{array}{l}\text { Blacks purchase from Blacks, buy from any } \\
\text { company (Grp) }\end{array}$ & .31 & .09 \\
\hline
\end{tabular}


Table 1 (cont.)

Factor Analysis of Pool of Delay of Gratification Items

(Black Student Leaders)

\begin{tabular}{|c|c|c|c|c|c|}
\hline \multirow[b]{2}{*}{ Dimension } & \multirow[b]{2}{*}{ Item\# } & \multirow[b]{2}{*}{$\begin{array}{l}\text { Factor I: Sociopolitical } \\
\text { Factor II: Achievement }\end{array}$} & \multirow[b]{2}{*}{$\begin{array}{l}52.3 \% * \\
47.7 \% *\end{array}$} & \multicolumn{2}{|c|}{$\begin{array}{c}\text { Varimax Rotation } \\
\text { Factors }\end{array}$} \\
\hline & & & & $I$ & II \\
\hline A & (15) & $\begin{array}{l}\text { Rent expensive apartment, o } \\
\text { later after graduation (Per) }\end{array}$ & ave money for & .06 & .66 \\
\hline A & (28) & $\begin{array}{l}\text { More difficult college majo } \\
\text { later, or easier major risk poo } \\
\text { ties (Career) }\end{array}$ & $\begin{array}{l}\text { for better job } \\
\text { er job possibili- }\end{array}$ & .15 & .61 \\
\hline A & (22) & $\begin{array}{l}\text { Have children now, wait un } \\
\text { lished (Career) }\end{array}$ & 1 career estab- & .02 & .57 \\
\hline A & (34) & $\begin{array}{l}\text { Take any job that comes ald } \\
\text { school for better job (Caree }\end{array}$ & g, or continue & .05 & .55 \\
\hline A & (5) & $\begin{array}{l}\text { Stay in school, or take ye } \\
\text { (Acad) }\end{array}$ & off to travel & -.03 & .53 \\
\hline A & (30) & $\begin{array}{l}\text { Take small tests and no com } \\
\text { or no tests but comprehensi }\end{array}$ & $\begin{array}{l}\text { ehensive final, } \\
\text { final (Acad) }\end{array}$ & -.05 & .52 \\
\hline A & (18) & $\begin{array}{l}\text { Study a little every day, or } \\
\text { (Acad) }\end{array}$ & am before test & .07 & .51 \\
\hline A & (25) & $\begin{array}{l}\text { Go to favorite concert and } \\
\text { grade, or stay home and stu } \\
\text { grade (Acad) }\end{array}$ & $\begin{array}{l}\text { sk getting bad } \\
\text { y to get better }\end{array}$ & .10 & .37 \\
\hline A & (35) & $\begin{array}{l}\text { Not take part in school clu } \\
\text { nates, or take part regardles }\end{array}$ & $\begin{array}{l}\text { that discrimi- } \\
\text { (Ind) }\end{array}$ & .14 & .35 \\
\hline A & (12) & $\begin{array}{l}\text { Take it easy in school, risk } \\
\text { work harder to get into } \\
\text { (Acad) }\end{array}$ & $\begin{array}{l}\text { wer grades, or } \\
\text { aduate school }\end{array}$ & .19 & .31 \\
\hline
\end{tabular}

Items not listed did not load significantly on either factor.

Eigenvalues: 4.04, 2.28; Variance: $21 \%$

Alpha: $.74, .68$

*Percent Total Variance Accounted For

**Percent Common Variance After Rotation 
The items loading more strongly on Factor 1 (eigenvalue $=4.04$ ) reflected a dimension tapping a general Sociopolitical domain. Those items loading on Factor II (eigenvalue $=2.28$ ) more closely represented what we label an Achievement Orientation in both career and academic domains. Close inspection of the 22 items revealed that although our original intent was to investigate Career and Academic domains separately, we concluded that the questions actually assessed a broader underlying domain of Achievement Orientation. A similar finding held for the Sociopolitical domain in that a factor emerged that reflected the sociopolitical issues at both the individual and group level.

\section{Descriptive Statistics}

The scores of the 12 items on the Sociopolitical dimension were summed and yielded a mean of 7.78 and a standard deviation of 2.81 . The scores of the 10 items on the Achievement dimension were summed and yielded a mean of 8.35 and a standard deviation 1.84. Correlations between the two subscales indicated that Sociopolitical Orientation and Achievement Orientation corelated .29. Although there was some overlap between the two scales, the factor analysis showed that each scale tapped a separate dimension of delay.

\section{Reliability Analysis}

Reliability statistics were computed for the two factors using Cronbach's alpha. The alphas for the two variables were relatively high, reflecting good reliability: sociopolitical $=.74$; achievement $=.68$.

\section{Gender Differences}

To further examine delay of gratification among Black student leaders, analyses of gender differences were conducted. As an estimate of such differences, principal component factor analysis with varimax rotation was conducted using those scale items that loaded significantly for both males and females on the sociopolitical and achievement dimensions. Table 2 shows the results of the factor structures that emerged from the total 16 items that comprised those two factors for both males and females -9 items on the sociopolitical dimension and 7 on the achievement dimension. As the table indicates, similar factor structures, i.e., sociopolitical and achievement, emerged for both sexes. 
Table 2

Factor Analysis of Pool of Delay of Gratification Items

(Black Male and Female Student Leaders)

\begin{tabular}{|c|c|c|c|c|c|}
\hline \multirow{2}{*}{$\begin{array}{l}\text { Dimen- } \\
\text { sion }\end{array}$} & \multirow[b]{2}{*}{ Item \# } & \multirow{2}{*}{$\begin{array}{l}\text { Factor: Sociopolitical- }(F) 20 \%,(M) 13 \% * \\
\text { Factor: Achievement-(F)12\%, }(M) 18 \%\end{array}$} & \multicolumn{3}{|c|}{$\begin{array}{c}\text { Varimax Rotation } \\
\text { Factors }\end{array}$} \\
\hline & & & & $I$ & II \\
\hline$S$ & (2) & $\begin{array}{l}\text { Take job with less pay now but more pay } \\
\text { later, or take job with more pay now } \\
\text { but few raises (Career) }\end{array}$ & $\begin{array}{l}(\mathrm{F}) \\
(\mathrm{M})\end{array}$ & $\begin{array}{l}.37 \\
.25\end{array}$ & .22 \\
\hline $\mathrm{S}$ & (4) & $\begin{array}{l}\text { Individual accept scholarship, or } \\
\text { refuse it (Ind) }\end{array}$ & $\begin{array}{l}(\mathrm{F}) \\
(\mathrm{M})\end{array}$ & $\begin{array}{l}.54 \\
.12\end{array}$ & .20 \\
\hline$S$ & (7) & $\begin{array}{l}\text { Blacks purchase from Blacks, buy from } \\
\text { any company (Grp) }\end{array}$ & $\begin{array}{l}(\mathrm{F}) \\
(\mathrm{M})\end{array}$ & $\begin{array}{l}.24 \\
.20\end{array}$ & $\begin{array}{r}-.09 \\
.36\end{array}$ \\
\hline$S$ & (14) & $\begin{array}{l}\text { Boycott and do without, or buy even if } \\
\text { discrimination exists (Grp) }\end{array}$ & $\begin{array}{l}(\mathrm{F}) \\
(\mathrm{M})\end{array}$ & $\begin{array}{l}.74 \\
.13\end{array}$ & $\begin{array}{l}.11 \\
.47\end{array}$ \\
\hline$S$ & (20) & $\begin{array}{l}\text { Blacks take best jobs, or work extra } \\
\text { in opposition to Apartheid (Grp) }\end{array}$ & $\begin{array}{l}(\mathrm{F}) \\
(\mathrm{M})\end{array}$ & $\begin{array}{r}.72 \\
-.19\end{array}$ & $\begin{array}{l}.01 \\
.74\end{array}$ \\
\hline $\mathrm{S}$ & (23) & $\begin{array}{l}\text { Shop nearby, or go elsewhere to avoid } \\
\text { discriminatory practices (Ind) }\end{array}$ & $\begin{array}{l}(\mathrm{F}) \\
(\mathrm{M})\end{array}$ & $\begin{array}{l}.62 \\
.25\end{array}$ & $\begin{array}{l}.00 \\
.31\end{array}$ \\
\hline$S$ & (26) & $\begin{array}{l}\text { Blacks refuse to sell to groups } \\
\text { supporting Apartheid or sell to } \\
\text { highest bidder (Grp) }\end{array}$ & $\begin{array}{l}(\mathrm{F}) \\
(\mathrm{M})\end{array}$ & $\begin{array}{r}.65 \\
-.12\end{array}$ & $\begin{array}{l}.16 \\
.60\end{array}$ \\
\hline$S$ & (29) & $\begin{array}{l}\text { Campaign for candidate, or not campaign } \\
\text { (Ind) }\end{array}$ & $\begin{array}{l}(\mathrm{F}) \\
(\mathrm{M})\end{array}$ & $\begin{array}{l}.46 \\
.18\end{array}$ & $\begin{array}{l}.06 \\
.35\end{array}$ \\
\hline$S$ & (38) & $\begin{array}{l}\text { Black students not accept scholarship } \\
\text { from Apartheid supporters, or accept } \\
\text { regardless (Grp) }\end{array}$ & $\begin{array}{l}(\mathrm{F}) \\
(\mathrm{M})\end{array}$ & $\begin{array}{r}.54 \\
-.13\end{array}$ & $\begin{array}{r}-.10 \\
.63\end{array}$ \\
\hline
\end{tabular}


Varimax Rotation

Factors

Dimen- Factor: Sociopolitical- $(F) 58 \%,(M) 53.3 \% * *$

sion Item \# Factor: Achievement- $(F) 42 \%,(M) 46.7 \%$ **

I II

A (5) Stay in school, or take year off to travel (Acad)

(F) $-.13 \quad .50$

(M) $\quad .60 \quad .01$

A (15) Rent expensive apartment, or save

(F) $\quad .18 \quad .54$

money for later after graduation (Per)

(M) $\quad .74 \quad-.01$

A (18) Study a little every day, or cram

(F) $\quad .05 \quad .63$ before test (Acad)

(M) $\quad .48 \quad .23$

A (25) Go to favorite concert and risk getting

(F) $\quad .09 \quad .50$ bad grade, or stay home and study to

(M) $\quad .31 \quad-.02$ get better grade

A (28) More difficult college major for better

(F) $\quad .17 \quad .56$

job later, or easier major risk poorer job possibilities (Career)

(M) $\quad .65 \quad .18$

A (30) Take small tests and no comprehensive final, or no tests but comprehensive final (Acad)

(F).$- .02 \quad .36$

(M) $\quad .58 \quad .08$

A (34) Take any job that comes along, or continue school for better job later (Career)

(F) $-.01 \quad .61$

(M) $\quad .61 \quad .07$

Eigenvalues- $F: 3.23$ (sociopol.), 1.89 (achieve.); $M: 2.94$ (achieve.), 2.03 (sociopol.) Variance- $F: 32 \% ; M: 31 \%$

Alpha—F: .76 (sociopol.); .60 (achieve.); $M$ : .62 (sociopol.); .68 (achieve.)

$*$ Percent Total Variance Accounted For

**Percent Common Variance After Rotation

$r(\mathrm{~S}, \mathrm{~A})=.21$ (for males and for females)

Note. When analyzed by gender, the sociopolitical dimension emerged as factor $I$ for females, but factor $I I$ for males; achievement emerged as factor $I I$ for females, but factor $I$ for males. 
Examination of gender differences in sociopolitical and achievement delay as well as perceived leadership indicated that: (1) males $(\overline{\mathrm{x}}=5.69, S D=$ $2.11)$ did not differ significantly from females $(\overline{\mathrm{x}}=5.89, S D=2.33)$ in sociopolitical delay $(t(1,316)=.71, p<1$; n.s. $) ;(2)$ females $(\overline{\mathrm{x}}=6.16, S D$ $=1.22)$ scored significantly higher than males $(\overline{\mathrm{x}}=5.39, S D=1.68)$ in achievement delay $(t(1,316)=3.71, p<.001)$; and $(3)$ although both groups indicated above average perceived leadership capability (range $=1-4$, low scoring reflecting greater leadership), males $(\overline{\mathrm{x}}=1.99, S D=.76)$ indicated greater perceived leadership than did females $(\overline{\mathrm{x}}=2.26, S D=.83 ; t(1,316)$ $=2.70, p<.01)$. These latter two findings are interesting because they suggest that Blacks' perceived leadership is not influenced solely upon achievement (i.e., academic and career) delay orientation. To examine this relationship further, stepwise multiple regression analysis was conducted to see whether either achievement or sociopolitical delay significantly predicted perceived leadership (Table 3 provides a correlation matrix for variables included in the regression models).

Results indicated that, for females, only sociopolitical delay was a significant predictor of perceived leadership, accounting for $6 \%$ of the variance $\left[F(1,213)=13.98, p<.001 ; B^{*}=-.09\right] .{ }^{2}$ For males, also, only sociopolitical delay significantly predicted perceived leadership, accounting for $8 \%$ of the variance $\left[F(1,101)=8.39, p<.01 ; B^{*}=-.10\right] .{ }^{2}$ These results suggest that for the Black male and female leaders in this sample, sociopolitical delay orientation was the better predictor of leadership.

$2 *=$ Partial regression coefficient

Table 3

Correlation Matrix for Variables in Regression Models

Sociopol. Achieve. PercLead.

Sociopol.

(Fem)

(M)

$.22 *(n=215)$
$19 *(n=103)$

$-.24 * *(\mathrm{n}=215)$

$-.27 * *(\mathrm{n}=103)$

Achieve.

$-.08(\mathrm{n}=215)$

$-.22 *(\mathrm{n}=103)$

PercLead.

\begin{aligned} & Note. $*=\mathrm{p}<.05 \\ & * *=\mathrm{p}<.01 \\ &$\hline\end{aligned}




\section{Discussion and Future Directions}

The results of the present study provide support for our notion of multidimensional delay of gratification. Specifically, support was found for: (a) sociopolitical delay (though individual and group levels of it did not emerge as separate factors) and (b) achievement oriented delay (though academic and career distinctions were not clearly established).

Closer inspection of the items designed to measure individual and group sociopolitical delay provide one possible explanation for the loading of both levels of this dimension of delay on one general factor. Several of the items asked essentially the same thing except at different levels. For example, one item tapped group delay preference regarding the purchase or acquisition of Black produced products for the sake of the survival of such companies, and another item focused on the same thing except at the individual level. It is unclear at this point in our research whether the finding of one general sociopolitical factor reflects (1) a close individual-group ethnic consciousness/identity unique to the type of subjects tested; (2) the developmental stage of the sample tested (i.e., the search for a clearly defined individual identity among these adolescents); or (3) whether sociopolitical delay preference is indistinguishable at the individual-group levels. Therefore, further delineation of this issue is warranted. For example, one might explore individual-level and group-level delay preferences for own-group/ other-group sociopolitical issues (e.g., ethnically and nonethnically relevant issues; gender issues, etc.).

The finding of a second factor, achievement-oriented delay, seems to reflect the close relationship between items we designed to tap academic delay preference and those we designed to tap career delay preference. The finding of this one general dimension seems reasonable given the fact that a primary and ultimate goal of academic success is quality preparation for and access to career goals and opportunities.

The failure to obtain support for the personal consumer dimension of delay is somewhat surprising. One explanation is that of context effects; that is, in anticipation of attending a student government leadership conference, students' responses may have reflected greater sensitivity to questions pertaining to achievement-oriented and sociopolitical issues. On the face of it, it seemed to us that a broader across-domain consistency that included consumer relevant delay might emerge in subjects' pattern of delay preference. It is possible that consumer relevant delay reflects a more direct, economy based thrust than do the others examined in this study, and that consumer choices to buy now or later, to spend now or save money are influenced by such current and impending factors as limited available resources. Further examination of 
this issue is warranted.

As stated in the Introduction, in addition to examining the multidimensionality of delay per se we were also interested in examining this phenomenon among Blacks. Regarding previous reviews of the literature that have shown Blacks to display either a pattern of preference for delay or as being indifferent toward some immediate versus delayed reward choices, the present line of investigation is important because it provides empirical evidence of distinct categories of delay that may influence Blacks' pattern of delay, nondelay, or indifference responding. Additionally, this line of work has implications regarding the functionality and perceived value of this aspect of self-regulation for this group of people. Ward et al. (in press) have raised questions concerning the functionality of the indiscriminate disposition to delay gratification, suggesting that such a tendency can be maladaptive in some circumstances (e.g., in instances where the choice to delay does not yield its assumed benefits). Identification, therefore, of specific relevant dimensions of delay and identification of patterns and choices among these dimensions among various groups of people can increase our understanding of the limits of the functionality of this construct of self-regulation and of when Blacks will display delay or nondelay preference or indifference to available options.

The examination of gender differences is important and warrants further examination. The finding of no differences in sociopolitical delay and that females displayed greater achievement delay orientation than did males in this study, but that males displayed greater perceived leadership, raises interesting issues. These findings suggest that factors other than achievement orientation as measured here significantly influence the perception of leadership within this group. As stated in the Introduction there exists a paucity of information about the psychological dynamics of delay preference among this select group of Blacks - male and female leaders. The present finding that neither Black male nor Black female leaders differed significantly in their sociopolitical orientation and that orientation was the better predictor of their perceived leadership may well reflect awareness of the ever-present sociopolitical influences that impact Blacks' welfare in the general society and that require the constant attention of all Black leaders as they strive toward the prosocial good. It also suggests that perceived leadership is associated with the willingness to sacrifice immediate gain.

Given that this sample consisted of male and female leaders, the finding that males expressed a significantly greater degree of perceived leadership than did females appears consistent with a pattern of findings that Black male graduate and professional students reported significantly higher selfconfidence and higher occupational aspirations, and did tend to major less 
often in traditional fields for Blacks such as education and social work than did females, despite the fact that females reported higher grade point averages (Hall, Mays, \& Allen, 1984). The extent to which leadership perception among the males studied here reflects a more general self-confidence or greater actual leadership activity is not known since data on the number and length of leadership involvements were unavailable in this study. It would be interesting to determine whether this finding holds when such aspects of leadership are controlled for.

Overall, the results of this initial study suggest that this line of investigation should be pursued further. Given these promising findings, instrument refinement as it assesses multidimensional delay is important for future research. Such refinement may include further verification of these newly established dimensions and the identification of other dimensions of this construct (even focus on other sociopolitical issues relevant to delay).

Recognizing the value of further instrument refinement and further definition of multidimensional delay, the current empirical evidence for the newly discovered sociopolitical dimension of delay is important. It provides evidence for the need to study further and systematically an aspect of selfregulation relevant to a better understanding of the psychological complexity involved in many current, real-life decisions and behaviors that are intended to further the social good.

In addition, directions for further research include the investigation of multidimensional gratification among minority students in different types of educational institutions. That is, the sample of Black students studied in this investigation attend predominantly White institutions. Identification of similarities and differences in multidimensional delay patterns in this population of students may lead to a better understanding of the types of Black students who attend these different educational institutions. It is of interest, for example, to know whether the same type of factor structure emerges for Blacks in historically Black institutions as it does for those in predominantly White institutions. Moreover, within each type of institution it is of interest to examine possible similarities and differences in delay preferences among Black student leaders and nonleaders.

Given the noted large proportion of Black students attending predominantly White institutions, a future direction of research could also include a comparison of Black and White students attending such schools. Finally, in addition to further study of the construct validity of multidimensional delay of gratification among different populations, issues such as predictive validity also need to be investigated. Do achievement-oriented or sociopolitical delay preferences significantly predict academic success (e.g., as measured in terms of GPA or persistence in school)? 
A better understanding of all of these issues may help to address the status of minority students in education. There currently exists considerable concern among educators and policy makers about the gross underrepresentation of minorities in higher education. That is, following increased numbers of minorities in higher education during the 1960s and 1970s, a noticeable decline in their representation has occurred in the 1980s. The problem of underrepresentation is particularly acute at the graduate level and the greatest problem of representation exists for Blacks (see Issac, 1985, for a discussion of the problem in psychology and Wilson \& Melendez, 1985, for higher education in general). It has become clear to all concerned that it is to the benefit of society as a whole that this decline be reversed. An issue of central importance to many educators, then, is a better understanding of factors that lead to the academic success of minority students, because the effective and successful development of these individuals will increase the production of future contributors to and leaders in society.

It is important to note that the underrepresentation of minorities in higher education is not fully explained by an understanding of the determinants of academic success; rather, it partly reflects what might be viewed as a delay of gratification decision made by many of today's youth. Specifically, in his examination of the demographic shifts occurring in America, Hodgkinson (1985) has pointed to the need to investigate reasons for the continued drop in the number of minority high school graduates who apply for college. He states that one out of eight " highly able" high school graduates decides not to attend college and that, despite the fact that $29 \%$ more Blacks graduated from high school in 1982 than in 1975, Black enrollment in college dropped $11 \%$ during that period. Similarly, Hispanic high school graduation rates increased 38\% during 1975-1982, but college enrollment declined 16\%. Hodgkinson then poses the question of why higher education is not appealing to America's minority high school graduates. Perhaps this choice on the part of many of America's minority youth, and youth in general, relates to the previously mentioned issue of the functionality of delay choices. It may be that the choice to attend college as a means of preparing for a subsequent career (i.e., a type of delay choice) is not perceived by such students to be their best option. That is, the more traditional routes of pursuing success may no longer be perceived as yielding their assumed benefits; hence, educational training is sought for example, in the military, in private business, and in industry, etc. The potential research issue this raises, then, is the examination of multidimensional delay preferences among individuals who choose to attend college and those who choose not to do so.

Beyond the educational implications of this line of research, such work may lead to broader theory development. For example, from the develop- 
mental perspective, it may be necessary to examine whether self-group distinctions emerge concerning sociopolitical issues at various ages and stages of individuals' socialization. Finally, sociopolitical delay of gratification should be examined among noncollege populations as well. It could be studied among existing political leaders, civil rights activists, and even among individuals who are exposed to various leadership training institutions and agencies.

\section{References}

Banks, W. C., McQuater, G. V., Ross, J. A., \& Ward, W. E. (1983). Delayed gratification in blacks: A critical review. Journal of Black Psychology, 9, 43-56.

Gurin, P., Gurin, G., Lao, R. C., \& Beattie, M. (1969). Internal-external control in the motivational dynamics of Negro youth. Journal of Social Issues, 25, 29-53.

Gurin, P., Gurin, G., \& Morrison, B. (1978). Personal and ideological aspects of internal and external control. Social Psychology, 41, 275-296.

Hall, M. L., Mays, A. F., \& Allen, W. R. (1984). Dreams deferred: Black student career goals and fields of study in graduate/professional schools. Phylon, $X L V, 271-283$.

Hodgkinson, H. (1985). All one system: Demographics of education, kindergarten through graduate school. The Institute for Educational Leadership, Washington, D.C.

Isaac, P. D. (1985). Recruitment of minority students into graduate programs in psychology. American Psychologist, 40, 472-475.

Lessing, E. (1969). Racial differences in indices in ego functioning relevant to academic achievement. The Journal of Genetic Psychology, 115, 153-167.

Mischel, W. (1961). Delay of gratification, need for achievement, and acquiescence in another culture. Journal of Abnormal and Social Psychology, 63, 543-552.

Mischel, W. (1974). Processes in delay of gratification. In L. Berkowitz (Ed.), Advances in experimental social psychology, Vol. 7. New York: Academic Press.

Mischel, W. (1986). Introduction to personality: A new look. New York: Holt, Rinehart, \& Winston. 
Price-Williams, D. R., \& Ramirez, M. (1974). Ethnic differences in delay of gratification. Journal of Social Psychology, 93, 23-30.

Sedlacek, W. E., \& Brooks, G. C., Jr. (1976). Racism in American education: A model for change. Chicago: Nelson-Hall.

Thomas, G. E. (Ed.). (1981). Black students in higher education: Conditions and experiences in the 1970s. Westport, Connecticut: Greenwood Press.

Tracey, T. J., \& Sedlacek, W. E. (1984). Noncognitive variables in predicting academic success by race. Measurement and Evaluation in Guidance, 16, 171-178.

Tracey, T. J., \& Sedlacek, W. E. (1985). The relationship of noncognitive variables to academic success. A longitudinal comparison by race. Journal of College Personnel, 26, 405-410.

Tracey, T. J., \& Sedlacek, W. E. (1986). Prediction of college graduation using noncognitive variables by race. Paper presented at the annual meeting of the American Education Research Association, San Francisco, April 1986.

Ward, W. E., Banks, W. C., \& Wilson, S. (In press). Delayed gratification in blacks. In R. L. Jones (Ed.), Black Psychology (3rd ed.). Berkeley: Cobbs \& Henry.

Wilson, R., \& Melendez, S. E. (Eds.). (1985). Fourth annual status report on minorities in higher education, Office of Minority Concerns, Washington, D.C.: American Council on Education. 